\title{
Policy Implementation of Educational Quality Improvement Based on National Education Standard
}

\author{
Lydia \\ SMP Negeri 2 Sekayu \\ e-mail: tentinglydia@gmail.com \\ Happy Fitria \\ Universitas PGRI Palembang \\ e-mail: happyfitriamufly@univpgri-palembang.ac.id \\ Yenny Puspita \\ Universitas PGRI Palembang \\ e-mail: yenny_puspitaa@yahoo.com \\ Article History: Received on 1 December 2020, Revised on 7 January 2021, \\ Published on 20 January 2021
}

\begin{abstract}
The objective of the study was to know the implementation of policies to improve the quality of education at SMP Negeri 2 Sekayu towards the National Education Standards. This study uses a qualitative method. Subjects in this study were school principals, Deputy for Facilities and Infrastructure, Student Associates, Teachers, and Students. Data collection was carried out by interview, observation, and documentation. Data were analyzed by data reduction, data presentation, and conculsion drawing. From the research results it can be concluded that the quality of education at SMP Negeri 2 Sekayu has met the requirements as a school with very good quality with the accreditation it has, namely the predicate "A" as a pilot school in Musi Banyuasin Regency. The National Education Standards that are applied are guided by the regulations issued by the Directorate General of Primary and Secondary Education, Ministry of Education and Culture in 2017 including, graduate competency standards, process standards, content standards, assessment standards, education and educational staff standards, facilities and infrastructure standards, standards management and financing standards have been implemented properly.
\end{abstract}

Keywords: Implementation, Quality of Education, National Education Standards

\section{A. Introduction}

Change is one of the things that is always attached to human life. Changes in human life occur continuously and continuously and are very dynamic. Nowadays people's life has undergone enormous changes with globalization, one of which is marked by the information revolution. This makes the world more open, thereby eliminating geographical, political, socio-cultural boundaries and other aspects of life. Hermino (2014) argues that globalization is seen as a phenomenon and a process that raises various faces, opinions and interpretations that cause various types and even dramatic impacts on humans, culture, and society.

Globalization provides increasingly complex demands for life, so there needs to be an awareness that improving the quality of human resources as actors in life is essential to be 
Volume 1 (3) 2020

E-ISSN: 2723-6919 P-ISSN:2746-0827

developed. One of the efforts to develop quality human resources is through education. Education is important in this regard as explained by Soetipto (2011) that based on the results of research on quality control of education, education plays a key role in the development of quality human and human resources. Quality human resources can be realized by a good educational process and from quality educational institutions (Rahmadoni, 2018; Asvio et al, 2019).

Education as an effort to improve the quality of human life, in essence, aims to humanize humans, mature, and change behavior, and improve quality for the better. Education has a role and strategic function in order to produce the children's creativity (Lian et al, 2018). All educational institutions in Indonesia have a duty and responsibility to build a generation that is potential and able to compete in the world market (Tobari et al, 2018). In reality, education is not a simple endeavor, but rather a dynamic and challenging activity. Education will always change along with changing times. At all times education is always the focus of attention and is often the target of dissatisfaction because education concerns the interests of all people, not only about the current conditions and atmosphere of life. That is why education always requires improvement and improvement in line with the increasing needs and demands of community life (Fatah, 2013).

This is in line with Law Number 25 of 2000 concerning the National Development Program (PROPENAS), which states that there are three major challenges in the education sector in Indonesia, namely (1) maintaining the results of education development that has been achieved; (2) preparing competent human resources and able to compete in the global job market; and (3) in line with the implementation of regional autonomy, the national education system is required to make changes and adjustments so as to realize a more democratic education process, pay attention to diversity, pay attention to regional needs and students, and encourage increased community participation (Hasbullah, 2016).

Efforts in facing the challenges of world development need a step in a strategic position in life, one of which is through political engineering. Political engineering is the definition of approaches, methods, strategies for formulating and implementing political policies that strictly regulate the implementation of education. In other words, political engineering is carried out through the formulation and implementation of educational policies. Educational policy is intended as a whole of decisions and legislation resulting from political processes and products governing education delivery. According to Hasbullah (2016) one of the political products that regulates the implementation of education is the presence of Law Number 32 of 2004 (starting with Law Number 29 of 1999) concerning Regional Government, in which a number of powers have been delegated by the Central Government to Regional Governments, enabling regions to create, innovate and improvise in developing their regions, including in the field of education. The enactment of the decentralization policy in the education sector does not automatically solve the various educational problems that exist in Indonesia. According to Hasbullah (2016) one of the educational problems faced by the Indonesian people is the low quality of education at every level and unit of education, especially primary and secondary education.

Since the birth of Law No. 20 of 2003 concerning the National Education System as expressed by Payong (2011) the focus of attention to improving the quality of education is becoming increasingly pronounced. This law has provided an important milestone for improving the quality of education through its attention to national education standardization. 
Volume 1 (3) 2020

E-ISSN: 2723-6919 P-ISSN:2746-0827

Another important milestone according to Payong (2011) is the birth of Law No. 14 of 2005 concerning Teachers and Lecturers which is an elaboration of Law No.20 / 2003. This law, which is often called the UUGD (Law on Teachers and Lecturers), specifically regulates teacher standardization (qualifications and competencies), rights and obligations, recruitment, placement and distribution, guidance and development, and protection and respect for teachers.

According to Muslich (2017) the issue of greatest concern in the world of education after the ratification of Law Number 14 of 2005 concerning Teachers and Lecturers in December 2005 is the issue of teacher certification. According to Muslich (2017) certification is the process of giving educator certificates to teachers who have met certain requirements, namely having academic qualifications, competence, being physically and mentally healthy, and having the ability to realize the goals of national education, coupled with an increase in decent welfare.

Payong (2011) through certification there is at least a guarantee and certainty about the professional status of teachers and also shows that license or certificate holders have certain abilities in providing professional services to the community. Many factors affect teacher performance, both external and internal factors (Maryati et al, 2020). Professional teachers have social responsibility manifested through teacher competence from the social environment and have effective interactive skills. Professional teachers believed to be able to make student think, behave and act creatively (Ruslan et al, 2020). Teachers must find learning methods so that students participate actively in the learning process (Kristiawan, 2013). According to Sagala (2011) the best service or excellent service is needed in every school so that students can learn optimally. According to Syafarudin (2010) school function to foster creative and innovative human resources, so that graduates meet the needs of society. Schools are required to find and implement a new strategy that can encourage quality improvement at the educational unit level. The principal faces greater challenges than the past in carrying out the duties and functions he plays on a daily basis (Komalasari et al, 2020). Leadership is a way to direct and influence subordinates for certain goals (Rahmadoni, 2018).

Astuti (2015) argues that improving the quality of schools is a systematic and continuous process to improve the quality of the teaching and learning process and the factors related to it, with the aim of becoming a school target that can be achieved more effectively and efficiently.

With the existence of Law No. 20 of 2003 article 51 paragraph 1 concerning the National Education System states that the management of early childhood education, basic education and secondary education units is implemented based on minimum service standards and the principles of School Based Management.

This presents the school as an institution that has the authority and authority in determining policies that are in accordance with the needs of the school and the vision and mission that are used as references in achieving goals, thus it is hoped that schools can improve the quality of education at the level of the educational unit. The term policy is often and broadly used in the context of government actions or activities and state behavior in general. This will be even more clear if it is followed by the views of a political scientist, Carl Fredrich (Hasbullah, 2016), which states that policy is an action that leads to the goals proposed by a person, group or government in a certain environment in connection with the existence of obstacles- certain obstacles while looking for opportunities to achieve goals or achieve 
Volume 1 (3) 2020

E-ISSN: 2723-6919 P-ISSN:2746-0827

desired goals. In the policy making process, it is a political process that takes place in the stages of political policy making, in this political activity it is described as a policy-making process, and is visualized as a series of stages that depend on each other, arranged according to time sequence, such as: agenda setting, policy formulation, policy adoption, policy implementation, and policy assessment (Hasbullah, 2016).

Referring to the stages described above, the researcher underlines the stage of policy implementation. Policy implementation is defined as the embodiment of decisions regarding basic policies, usually contained in a law, but can also take the form of important executive instructions or statutory decisions. According to Hasbullah (2016) as a measure of the success of education policy, it can be seen in how it is implemented. Policy formulations that are made do not just stop at the formulation order, but must be functionally implemented. No matter how good the policy formulation is, if it is not implemented, the benefits will not be felt. On the other hand, no matter how simple the policy formulation is, if it is implemented, it will be more useful, regardless of the outcome. The implementation of a policy itself is in the form of programs which are then realized through an activity.

National education standards contain minimum criteria regarding educational components that allow each level and path of education to develop education optimally in accordance with the characteristics and peculiarities of the program. The scope of the National Education Standards (SNP) includes: (1) content standards; (2) process standards; (3) competency standards of graduates; (4) standards of educators and educational personnel; (5) standard of facilities and infrastructure; (6) management standards; (7) standard of financing; and (8) education assessment standards. The National Education Standards function as the basis for planning, implementing, and supervising education in the context of realizing quality national education. To guarantee and control the quality of education in accordance with the National Education Standards, evaluation, accreditation and certification are conducted.

In assessing the implementation of national education standards, the government accredits every level of education units, as contained in Government Regulation Number 19 of 2005 concerning National Education Standards Chapter XIII Article 86, it is determined that 1) The government accredits each level and education unit to determine the feasibility of the program 2) The accreditation authority as referred to in paragraph 1 can also be carried out by an independent institution that is authorized by the Government to carry out accreditation, 3) Accreditation as referred to in paragraph 1 and paragraph 2 as a form of public accountability is carried out objectively, fairly, transparently, and comprehensively by using instruments and criteria that refer to the National Education Standards.

With the enactment of the National Education Standards, the government has an interest in mapping schools into schools that have or are close to meeting the National Education Standards. In this regard, the government categorized schools that had met or nearly met the National Education Standards into the independent category, and schools that had not met the National Education Standards into the standard category.

Various efforts have been made to prioritize the allocation of central government and regional government resources to assist schools that are still not standardized into the standard category and from the standard category to be able to upgrade themselves to the independent category against schools that are already categorized as independent. The government is pushing it to gradually reach international level. Researchers are interested in 
Volume 1 (3) 2020

E-ISSN: 2723-6919 P-ISSN:2746-0827

conducting research at SMP Negeri 2 Sekayu due to the status of the school that has been accredited $\mathrm{A}$ and has adequate facilities and infrastructure to support quality improvement towards the National Education Standards.

\section{B. Methods}

The method here describes what methods are used in research. With the method is expected to be a guide for researchers in carrying out research in accordance with the goals and objectives to be achieved. The method in this study uses a qualitative descriptive method with a case study approach. According to (Moleong, 2009). Meanwhile, according to Sudjana (2010), qualitative research is often used to produce grounded theory, which is a theory that arises from data not from hypotheses like in quantitative research. In general, case studies are a more suitable strategy when the research question is about how or why, if the researcher has little opportunity to control the events to be investigated, and when the focus of his research lies on contemporary (present) phenomena in the context of real life.

\section{Results and Discussion}

The National Education Standards include eight criteria that must be met in the effort to achieve quality education at SMP Negeri 2 Sekayu. The eight national standards consist of:

\section{Standard Content}

The implementation of content standards at SMP Negeri 2 Sekayu in order to achieve national education standards as an effort to improve the quality of education can be seen from the results of interviews previously described, where informants from Indonesian language teachers stated that content standards were implemented or compiled at the beginning of the new academic year which includes the preparation of a Learning Implementation Plan, syllabus and other learning tools as a requirement for supervision to improve the quality of education.

In addition, the curriculum used is the 2013 curriculum by implementing various learning strategies, namely discussion, problem solving, especially in integrated science learning materials, namely Biology and Physics and also computer laboratories. Curriculum innovation can be defined as deliberate actions to improve a learning environment by adopting a method of presenting material to students that involve human interaction, handson activities, and student feedback (Wachidi, 2019).

Content standards include the scope of material and the level of competence to achieve the competence of graduates at certain levels and types of education. Content standards contain the basic framework of the curriculum structure, study load, curriculum at the educational unit level, the academic calendar. The educational curriculum can be classified into two parts, namely content and process (Tilaar, 2014). The curriculum as an educational process is related to the independence of the material presented by the teacher (how it is delivered) to students, while the content of the curriculum is related to relevance, interdisciplinary conditions and characteristics of knowledge and learning experiences related to what students learn. 
Volume 1 (3) 2020

E-ISSN: 2723-6919 P-ISSN:2746-0827

Returning the authority to local educators (teachers) is more promising that there will be no ugliness. If it is analyzed from the aspect of regulatory provisions, consistency, authority and power, the policy of controlling the curriculum by the state seems to release a number of flexibility for schools, regions and teachers. Control and control of the curriculum by the state is specifically carried out on several important elements. The elements referred to include: graduation requirements, learning outcomes tests, guidelines and curriculum for national subjects, school evaluation and certification, material selection processes, teacher certification requirements, and school management information systems (Mulyasa, 2016).

The curriculum is not only content and material but school goals and objectives and assessment strategies for how to achieve them. The curriculum includes teaching techniques and strategies, learning activities in the form of space and time use or all planned student activities.

\section{Process Standards}

In this process standard, the informant or resource person, namely the principal of SMP Negeri 2 Sekayu, explained that the process standard was part of an effort to improve the quality of education towards the National Education Standard, the principal explained various things related to the standard process.

Learning at the beginning of the semester is carried out by the preparation of learning tools by the teachers which will be applied for one year which includes odd and even semesters. To make this a success, the school facilitated the implementation of the MGMP (subject teacher deliberation) at the Musi Banyuasin district level which was held at SMP Negeri 2 Sekayu.

In the MGMP activity, learning strategies are discussed that can improve student learning outcomes and stimulate students' ability to be active and seek learning information on their own, the teacher is only involved as a facilitator. The educational process is the key to the ongoing learning process, in which educational programs are implemented. The learning process that has not been smooth and bad in many of our schools has resulted in the low quality of education. The quality of the learning process is very dependent on various aspects, especially supporting facilities including buildings and equipment facilities, and especially teachers and the learning atmosphere.

School effectiveness is influenced by epistemological problems and political obstacles that are often not serious enough to direct policy. The effectiveness and efficiency of schools is a reflection of its goals and achievements (learning outcomes). Important process variables in education are the classroom atmosphere and school environment, standard facilities and management, and interactions between individuals and the environment (Mulyasa, 2016).

The main problems of quality relate to the value system, code of ethics, standard behavior of students both in schools and in society at large need to be involved in assessment policies and practices. In addition to the factors above, the reality in many schools where the learning process in a conducive atmosphere does not materialize, because of the weaknesses of teachers who teach in old ways and do not involve students actively. Also because of the teacher's abilities, competencies and attitudes that do not support the creation of a quality learning process. So, the educational process is largely determined by other educational 
Volume 1 (3) 2020

E-ISSN: 2723-6919 P-ISSN:2746-0827

variables or indicators such as: the carrying capacity of facilities, a conducive learning atmosphere or climate, as well as by the competence and attitude of teachers.

\section{Competency Standards of Graduates}

Information on graduate competency standards is obtained from wakasek informants who explain the standards that must be met by a graduate at SMP Negeri 2 Sekayu as an effort to improve the quality of education through the National Education Standards.

The information obtained shows that the competency standards of graduates have been prepared in advance and grouped various criteria such as faith, piety, self-confidence, responsibility, which are classified as attitude criteria. While the criteria for knowledge are in the form of knowledge, insight and science and technology.

The quality of education is also determined and measured by the quality of the graduates produced by certain educational institutions, and the quality of educational institutions on the contrary is also assessed by the quality of the graduates it produces. From time to time the competence of graduates becomes an issue, and the educational variable that is affected is the educational institution evaluation system.

The phenomenon of the evaluation system that has not guaranteed the competence of graduates is clear from school graduation that reaches $100 \%$ every year, while those who pass purely from the selection of new student admissions at State Senior High School (SMA) in Musi Banyuasin Regency have reached 90\%.

Competency standards for graduates lie in the formulated educational goals and curriculum content. The relevance of a curriculum that is oriented towards the needs of employment will be able to guarantee the quality of graduates who are ready to enter the world of work, if supported by a good educational process. Here the insight into teacher knowledge recognizes the competencies needed by students, it will also be very helpful in the preparation process. Furthermore, schools, especially teachers, need to focus attention on collaborative consultations rather than on supervision or defense activities. Thus creating an atmosphere of dialogue between students and teachers (Dakir, 2014).

So that children get support to become members of the community. A quality school provides a curriculum, academic activity which is a fundamental right of students, which can guarantee the achievement of quality education that is relevant to needs.

\section{Educators and Education Personnel Standards}

Teachers are educators, which are competent professional skills in the field of education. In the process of globalization where changes occur very rapidly, teachers are required to constantly adjust their competence to these developments. Tilaar, H.A.R., (2014: 141-142) wrote: today teachers participate in the process of change and development especially in preparing intelligent citizens and skilled manpower. In line with efforts towards universal basic education, a large number of teachers are required, mostly in a short time. This has bad effects on the teaching profession, the requirements for entering the teaching profession are reduced. As a result the image of teaching profession is severely tarnished. The image of the teaching profession of yesterday has gone. 
Volume 1 (3) 2020

E-ISSN: 2723-6919 P-ISSN:2746-0827

We see many teachers in big cities who have the competence to teach and carry out their duties professionally. Human resources must be empowered in information technology to become professional teachers (Rahmadoni, 2018). However, in many places in the regions and remote areas, many educators are of inferior quality. This is one of the reasons why the quality of our education is low. However, it seems that the quality of education does not want to be related to the quality of teachers.

To restore the image and perception of society towards the teaching profession, various efforts are needed to raise teacher competence, including providing stimulation to the nation's young generation who have the potential to be interested in and cultivate this profession. In a modern society that is oriented towards fulfilling welfare, in the future, rewards with reasonable rewards and incentives are an alternative solution, in addition to (for the present) the realization of teacher competency standards through a professional readiness (feasibility) evaluation mechanism needs to be done.

\section{Standard of Facilities and Infrastructure}

The standard of educational facilities and infrastructure includes study rooms, sports places, places of worship, libraries, laboratories, workshops, playgrounds, places for recreation and recreation, and other learning resources needed to support the learning process, including the use of information and communication technology, and facilities. other teaching and learning (Muslich, 2017). The fulfillment of this education standard depends very much on the allocation of education funding, but also on the part of the community and the parents of those who can afford it. Reform in the field of education that prioritizes improving the quality of education, of course, needs to also be accompanied by an increase in the quality of adequate educational facilities and infrastructure.

The standard of facilities and infrastructure should prioritize the factor of ensuring the safety of children's learning and the stability of the carrying capacity of the learning process. The issue of educational facilities and infrastructure is closely related to education financing. The government's ability to support the improvement of facilities and infrastructure is still very limited. While there are people in the community who claim "free education". This is a serious challenge for BSNP in formulating standard education indicators.

Moreover, in the regional autonomy policy, education funding is less of a concern for the rulers in the regions, so the negative impact of the decline in education will become a new threat (Mulyasa, 2016). Standard facilities and infrastructure are required for each educational unit for its procurement and maintenance. This is a challenge for the largest part of the education unit in the country. This aspect of standard setting needs to organize the procurement and maintenance system by involving the parents of students and the community around the education unit. Including the obligations of stakeholders, to assist the government in supporting and ensuring the availability of appropriate learning facilities for education.

\section{Management Standards}

The education management in National Education Standard arranges the education management level in: education unit level management standards, management standards by local governments, management standards by the (central) government. The division of authority for education management is in line with the government decentralization strategy 
which also involves the management of education. UU no. 32 of 2004 concerning Regional Autonomy (article 13 paragraph 1: f) delegates part of the authority for the management of education in the regions to regional governments.

This policy provides an opportunity for regions to manage and develop the education sector according to the potential and conditions of each region. On the one hand, it can spur the development of the world of national education (for regions with adequate financial capacity and human resources), but on the other hand, it can have an impact on the deterioration of the quality and management of education in other regions. Thus, it can result in widening the education gap among the nation's children. Good and optimal education management is needed to support the synergy of the learning process which is the main point of management at the education unit level. However, regional and national needs also require cooperative relationships to meet mutual needs.

\section{Financing Standard}

Education performance will be poor if it is not balanced with an adequate budget. Modern life in global society, must experience the reality that "education is expensive". The leaders of this country actually realize that the education budget is important, they know that the future of the nation is very much dependent on the quality of education. However, knowledge and awareness of the importance of education funds, according to Muslich (2017)mare not matched by adequate commitment and discipline."

Education financing can be in the form of investment costs, operating costs and personal costs. The education funding that is provided by the government is still limited to the investment cost assistance for the provision of educational facilities and equipment, as well as operational costs for the provision of education that support the implementation of a good and successful learning process.

One important factor that is overlooked or "forgotten" or "unreachable" is the personal cost that can directly ensure the readiness of students to be involved in learning activities. Student readiness depends on physical and mental readiness, then on the readiness of instructional support tools.

Future education funding needs to consider priority needs based on creating conditions for children's readiness to learn. Analysis of education financing standards appropriately involves all three types of education financing. The allocation of government education funds should pay attention to the minimum standard requirements per student, in addition to the principles of equity and justice.

Government policies and capabilities in terms of funding are limited to supporting operational costs of education, where there are many "leakages", inadequate salaries for teachers and education personnel, affecting quality achievement.

\section{Educational Assessment Standards}

Educational assessment includes assessment of learning outcomes by educators, by educational units, by the government, and graduation. Evaluation is an effort to improve quality. The implementation of evaluation by the teacher is more appropriate if it is done to 
Volume 1 (3) 2020

E-ISSN: 2723-6919 P-ISSN:2746-0827

help students learn, or by the school to correctly explain the achievement of student learning outcomes. Class assessment is a process of collecting data and using information by teachers to make decisions, in this case the value of student learning outcomes based on their learning stages.

Class assessment is carried out in various ways such as written tests (paper and pencil tests), portfolios (assessment of work results through a collection of work results, product assessments, project appraisals, and performance assessments. Ministry of National Education Center for Curriculum Balitbang provides guidelines for classroom assessment with techniques assessment techniques: performance, attitudes, writing, projects, products, and portfolios as well as self-assessment as a reference for teachers in implementing competency-based assessments. If this system is fully implemented by teachers in learning activities, the consequences that must be faced are that teachers are required to be increasingly professional in carrying out their duties

The birth of the educational system law and strengthened by other regulations, including regulations related to National Education Standards, the direction and achievements of national education are increasingly clear. The eight established education standards are considered to represent the holistic needs of the delivery of national education. The National Education Standards are the minimum criteria regarding various relevant aspects in the implementation of the national education system and must be fulfilled by education providers or educational units in all jurisdictions of the Republic of Indonesia. The National Education Standards serve as the basis for planning, implementing and supervising education in the context of realizing quality national education. The National Education Standards aim to guarantee the quality of national education in order to educate the nation's life and shape the character and civilization of the nation with dignity. National Education Standards are perfected in a planned, directed and sustainable manner in accordance with the changing demands of local, national and global life.

The implementation of SNP in schools at every level is the minimum criterion that must be met as a measure of achievement in an educational administration. One of the positive implications of the achievement which is the result of consistency in implementing this SNP is the birth of the advantages possessed by the school.

\section{Conclusion}

Based on the results of data descriptions and discussion of the implementation of policies for improving the quality of education at SMP Negeri 2 Sekayu Towards National Education Standards, it can be concluded as follows 1) The quality of education at SMP Negeri 2 Sekayu has met the requirements as a school with very good quality with the accreditation it has, namely the predicate "A" as a pilot school in Musi Banyuasin Regency; and 2) The National Education Standards applied are guided by the regulations issued by the Directorate General of Primary and Secondary Education of the Ministry of Education and Culture in 2017 which include graduate competency standards, process standards, content standards, assessment standards, education and educational staff standards, facilities and infrastructure standards, management standards and financing standards have been implemented properly. 


\section{E. Acknowledgement}

Our deepest gratitude goes to the Principal of SMP Negeri 2 Sekayu, Chancellor of the PGRI Palembang University, Director of the PGRI Palembang University Postgraduate Program and the PGRI Palembang University Education Management Study Program who have supported us to do this extraordinary thing. This project is independently funded. We would also like to thank our friends in Education Management who helped us a lot in completing this project in a limited time frame.

\section{References}

Astuti, D. (2015). Desentralisasi dan Partisipasi Masyarakat dalam Pendidikan [ Decentralization and Community Participation in Education]. Yogyakarta: Pustaka Pelajar.

Asvio, N., Yamin, M., \& Risnita. (2019). Influence of Leadership Style, Emotional Intelligence and Job Satisfaction toward Organizational Commitment (Survey at SMA Muhammadiyah South Sumatera). International Journal of Scientific \& Technology Research 8 (8).

Dakir. (2014). Perencanaan dan Pengembangan Kurikulum [Planning and Curriculum Development]. Jakarta : Rineka Cipta.

Fatah, N. (2013). Sistem Penjaminan Mutu Pendidikan [Education Quality Assurance System. Bandung: PT Remaja Rosdakarya.

Hasbullah. (2016). Otonomi Pendidikan [Educational Autonomy]. Jakarta: PT RajaGrafindo Persada.

Hermino, A. (2014). Kepemimpinan Pendidikan Di Era Globalisasi [Educational Leadership in the Era of Globalization]. Yogyakarta: Pustaka Pelajar.

Komalasari, K., Arafat, Y., \& Mulyadi, M. (2020). Principal's Management Competencies in Improving the Quality of Education. Journal of Social Work and Science Education, 1(2), 181-193. Retrieved from https://ejournal.karinosseff.org/index.php/jswse/article/view/47

Kristiawan, M. (2013). The Implementation of Cooperative Learning in English Class of Favorite School of Secondary High School 5 Batusangkar, West Sumatera. International Journal of Educational Administration and Policy Studies, 5(6), 85-90.

Lian, B., Kristiawan, M., \& Fitriya, R. (2018). Giving Creativity Room to Students through the Friendly School's Program. International Journal of Scientific \& Technology Research, 7(7).

Maryati, E., Fitria, H., \& Rohana, R. (2020). The Influence of Principal's Leadership Style and Organizational Culture on Teacher's Performance. Journal of Social Work and Science Education, 1(2), 127-139. Retrieved from https://ejournal.karinosseff.org/index.php/jswse/article/view/38 
Moleong, L. (2009). Penelitian:Kualitatif [Research: Qualitative]. Bandung: Alfabeta.

Mulyasa, E. (2016). Menjadi kepala sekolah Profesional [Become a professional school principal]. Bandung: PT. Remaja Rosdakarya.

Muslich, M. (2017). Sertifikasi Guru Menuju Profesionalisme Pendidik [Teacher Certification Towards Educator Professionalism]. Jakarta: Bumi Aksara.

Payong, M. R. (2011). Sertifikasi Profesi Guru (Konsep Dasar, Problematika, dan Implementasinya) [Teacher Professional Certification (Basic Concepts, Problems, and Implementation)]. Jakarta: PT Indeks.

Rahmadoni, J. (2018). Isu Global Manajemen Pembiayaan Pendidikan di SD Indonesian Creative School Pekanbaru [Global Issues of Education Financing Management at SD Indonesian Creative School Pekanbaru]. Jurnal Manajemen, Kepemimpinan dan Supervisi Pendidikan 3(2).

Rahmadoni, J. (2018). Perancangan Simulasi Pembelajaran Kriptografi Klasik Menggunakan Metode Web Based Learning [Designing Classical Cryptography Learning Simulation Using Web Based Learning Method]. INTECOMS: Journal of Information Technology and Computer Science, 1(1), 34-43. https://doi.org/https://doi.org/10.31539/intecoms.v1i1.160

Ruslan, Lian, B., \& Fitria, H. (2020). The Influence of Principal's Situational Leadership and Teacher's Professionalism on Teacher's Performance. International Journal of Progressive Sciences and Technologies (IJPSAT), 20(1).

Sagala. (2011). Kemampuan Profesional Guru dan Tenaga Kependidikan [Professional Capabilities of Teachers and Education Personnel]. Bandung: Alfabeta.

Soetipto \& Kosasi, R. (2011). Profesi Keguruan [Teaching Profession]. Jakarta: Rineka Cipta.

Sudjana. (2010). Statistik Penelitian [Research Statistics]. Bandung: Alfabeta.

Syafarudin, S dan Makmun, A. S. (2010). Perencanaan Pendidikan: Suatu Pendekatan Komprehensif [Educational Planning: A Comprehensive Approach]. Bandung: Remaja Rosdakarya.

Tilaar, H.A.R. (2014). Standarisasi Pendidikan Nasional, Suatu Tinjauan Kritis [National Education Standardization, A Critical Review]. Jakarta: Rineka Cipta.

Tobari., Kristiawan, M. \& Asvio, N. (2018). The Strategy of Headmaster on Upgrading Educational Quality in Asean Economic Community (AEC) Era. International Journal of Scientific \& Technology Research 7 (4). 
Journal of Social Work and Science Education

Volume 1 (3) 2020

E-ISSN: 2723-6919 P-ISSN:2746-0827

Wachidi. (2019). Teachers' Stage of Concern in Implementing Elementary School Curriculum Innovation. International Journal of Educational Review Vol. 1, Issue. 2, 27-34. Retrieved from https://ejournal.unib.ac.id/index.php/IJER/article/view/8843 